\title{
Research \\ How to Set Up a Research Framework to Analyze Social-Ecological Interactive Processes in a Rural Landscape
}

\author{
Marc Deconchat $^{1}$, Annick Gibon $^{1}$, Alain Cabanettes ${ }^{1}$, Gaétan du Bus de Warnaffe $^{1}$, Mark Hewison ${ }^{2}$,

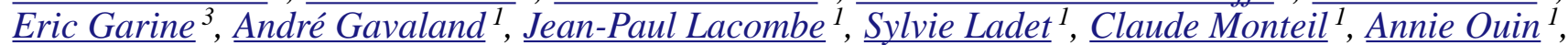 \\ Jean-Pierre Sarthou $^{1}$, Anne Sourdril $^{1}$, and Gérard Balent ${ }^{1}$
}

\begin{abstract}
Interdisciplinary research frameworks can be useful in providing answers to the environmental challenges facing rural environments, but concrete implementation of them remains empirical and requires better control. We present our practical experience of an interdisciplinary research project dealing with non-industrial private forestry in rural landscapes. The theoretical background, management, and methodological aspects, as well as results of the project, are presented in order to identify practical key factors that may influence its outcomes. Landscape ecology plays a central role in organizing the project. The efforts allocated for communication between scientists from different disciplines must be clearly stated in order to earn reciprocal trust. Sharing the same nested sampling areas, common approaches, and analytical tools (GIS) is important, but has to be balanced by autonomy for actual implementation of field work and data analysis in a modular and evolving framework. Data sets are at the heart of the collaboration and GIS is necessary to ensure their long-term management and sharing. The experience acquired from practical development of such projects should be shared more often in networks of teams to compare their behavior and identify common rules of functioning.
\end{abstract}

Key Words: fragmented forest; interdisciplinary research; landscape ecology

\section{INTRODUCTION}

The close links between human activities and environmental processes call into question our collective ability to identify, within the complex functioning of social systems, what impact human activities have on ecological phenomena and to propose operational responses to manage them (Southwood 1995, Legay 2006). Rural areas are facing rapid changes and uncertainty in the agricultural and forestry fields that affect their future (Deffontaines et al. 1995). Finding effective answers to such issues is hampered by the difficulty in designing functional research frameworks to deal with such large and fuzzy questions (Sébillote 2001). Because they are both social and ecological in nature, these questions must be approached using an interdisciplinary framework that provides an integrative view (Holling 1998, 2001) of the reciprocal interactions between the two systems (Jollivet 1992, Boiffin 2004). However, creating interdisciplinary research frameworks is not simply a matter of juxtaposing disciplines, nor of forcing a continuous interaction-and even less that of an illusory combination-but rather one of developing a dynamic and specific operating mode for research (Delattre 1985). Defining rules to build and manage such interdisciplinary research frameworks better, faster, and more effectively represents, in its own right, a useful quest to respond to current environmental challenges.

We believe that a method to set up an interdisciplinary research framework must be developed from a theoretical analysis of how research is conducted, dealing with questions of scales and models (Holling 2001), but also taking into consideration the practical constraints that strongly shape current research activities and yet have received less interest. We aim to identify some key practical factors for more efficiently setting up an interdisciplinary research project dealing with 
ecological and societal relationships. We present our experience acquired during a study of relationships between biodiversity and woodlot management in non-industrial private forests (NIPFs) (Carlsson et al. 1998) in a fragmented landscape in the Gascony hillsides of southwestern France. From this, we propose recommendations for other interdisciplinary research projects. We analyze the project from four points of view, including organizational and practical aspects: the preliminary context framework, the goals and strategy of the research, the results, and finally, an analysis of the management and methodological aspects. The results presented for each of these points of view are grouped in four sections, with a discussion to identify key factors contributing to the success or the difficulty in reaching the project's goals: 1) the framework of the project; 2) the management of the project; 3) the methodological aspects of the project; and 4) the results of the project.

\section{THE FRAMEWORK OF THE PROJECT: AN INTERDISCIPLINARY STUDY ON BIODIVERSITY AND MANAGEMENT OF WOODLOTS}

\section{Rationale and Genesis of the Project}

Non-industrial private forests (NIPFs) are a typical feature of many European landscapes. In France, 2.4 million private woodlot owners each own less than 1 ha of forest; the Midi-Pyrénées region has the highest proportion of private owners $(80 \%)$, most of whom are rural owners of small fragments (Inventaire Forestier National (IFN) 2006). Relative to their small area, NIPFs have an important place in landscapes because of their ecological role, as well as their agronomic, social, and esthetic functions (Sauget 1994). Therefore, they must be taken into account when considering global landcover changes.

At the beginning of the 1990s, three scientists from the Institut National de la Recherche Agronomique (INRA; French National Institute for Agricultural Research) began studying the role that small fragmented forests play in rural landscapes, as an offshoot of their earlier studies dealing with ecology and farming relationships, and because of new demands from regional land managers. At the same time, a second INRA team studying roe deer (Capreolus capreolus) population dynamics began collaborating on the same sites. A book synthesizing this phase (Balent 1996) was the starting point for a scientific thematic approach centered on NIPF ecology and management in rural landscapes. From 1992 to 2002, research activities were carried out by various team members, under various administrative structures, but with the same leaderdirector; since then, this topic has been the focal interest of a research team (Dynafor) that was officially created in 2003, and which includes another team dealing with landscape dynamics.

Dynafor was created as an interdisciplinary research unit under the aegis of an interdisciplinary research project about prospective studies for French regional development (PSDR program: http://www. inra.fr/rhone-alpes/symposium/problematique.htm ), which was funded in 2002 by the Midi-Pyrénées regional council and INRA; it was coordinated by scientists who are now part of Dynafor. Its title was "Multifunctionnality of small fragmented forests in the Gascony hillsides" and it had two objectives: 1) to explore how coppice (the main silvicultural system in Midi-Pyrénées region) with standard management can contribute to both sustainable agriculture and forestry, and 2) to explore how woodlots can contribute to environmental functions.

\section{General Theoretical Framework and Strategy of the Project}

The need to be able to cope with "fuzzy" and "soft" questions requires placing them in an appropriate conceptual framework (Gibon 2003). The design of the project was based on a conceptual framework of ecological and social systems and their interrelationships, which was previously developed by the project leader and some of the research team members from interdisciplinary field research studies on changes in agricultural systems and their impacts on ecological systems (Balent 1987, Di Pietro and Balent 1997, Balent and Gibon 1999). This conceptual framework consisted of a systemic model developed from complex system theories (Allen and Starr 1982, Blandin and Lamotte 1985, Jollivet and Pavé 1993) and their applications in agricultural sciences (Thornton and Jones 1998, Deffontaines et al. 1995, Papy 2001) and landscape ecology (Forman and Godron 1986).

The project design recognized the importance of simultaneously taking into account social and 
ecological systems, seen as co-evolving systems, in order to address the question of sustainable natural resource management (Folke et al. 1996, Berkes and Folke 1998, Berkes 1999, Bingeman et al. 2004 Maczko et al. 2004, Olsson et al. 2004). In this perspective, empirical experience accumulated by rural societies (i.e., folk knowledge) constitutes an invaluable source of information that, in concert with academic knowledge generated by research experiments, can help improve the management of natural resources (Ellen 1982, Reid et al. 1992). Human sciences, such as sociology and anthropology, provide necessary viewpoints for dealing with these questions (Toledo 1992, Abel and Stepp 2003).

Ecological systems were considered according to their biodiversity and animal population dynamics (Chapin et al. 1992, Huston 1994). The project was designed to study biodiversity patterns and to compare the influence of human practices (mainly logging) with that of other factors (e.g., edaphic conditions, dispersal). This implied that situations not relevant to a usual management practice could be studied in order to create a complete model of the ecological phenomena over the whole range of its variability. For example, the influence of woodlot area on biodiversity was studied over a sample territory that included some very large forests even though they were not common across the landscape. Spatial factors (distance for dispersal, area of the fragments) were recognized for their importance in many ecological processes in studied fragmented landscapes, and strongly influenced the methodologies (Forman and Godron 1986). Because of the scale, which was often large, and because of their nature, the phenomena being studied cannot generally be repeated or controlled, but can be observed only through case studies that need adapted analysis.

Land management practices were seen as the concrete interface between ecological and social systems. Management practices are deliberate acts aimed at influencing ecological processes in order to steer them in a desired direction, in response to estimates of current or future needs (Sébillote 1992, Balent et al. 1999). However, such practices are not the only control factors because human activities can have unintended ecological consequences. The study of these management practices represents a major line of investigation for broaching the question of the relationship between human activities and nature (Berkes and Folke 1998). The partnership between research and other actors in society concerned directly or indirectly with the questions examined played a central role in the project, not least because social studies necessarily imply an acceptance among the people to be studied, but also because of the applied nature of the project, which was intended for regional development. The topicality of certain questions lends them an urgency that sometimes energizes the research, but also necessitates providing incomplete answers, within imperfect frameworks. Although the relevant processes often concern long periods, answers must be provided before they have been completely elucidated (Walker et al. 2004). This leads to uncertainty concerning the results produced, which it will be necessary to come to terms with in order to help decision makers make their choices.

\section{THE MANAGEMENT ASPECTS OF THE PROJECT}

\section{Human Resources}

Twenty-five people were involved over the 3 years of the project. Landscape ecology, which was the project manager's discipline, was the common denominator for the project's tasks; $30 \%$ of the scientists had ties to this discipline. The other participants recognized it as an integrative discipline toward which the other studies might converge regularly and at a final point. Forest ecology and forestry sciences were the second main fields (20\%), but entomology and agro-ecology, more recent additions to the research team, were nevertheless accorded equal importance. Social sciences involvement (15\%) was based on collaboration with other research units from several institutes and universities, and on co-supervision of $\mathrm{PhD}$ candidates. Methodological skills, such as geographic information systems (GIS), spatial modeling, and remote sensing, implicating about $20 \%$ of the staff, were used by all the other disciplines and occupied a central place in the general framework of the project. A technical group (four people), in combination with students (five each year), provided fieldwork support. Collaboration with other teams on the same study sites was ongoing and involved scientists studying roe deer ecology in fragmented landscapes (four scientists), and remote sensing and biometry (two scientists). 


\section{Coordination between Project Members}

As stated previously, landscape ecology was identified by most members of the project and its partners as a core, overarching discipline that set the tone for most of the cooperation, collaboration, and communication between the different components of the project. We estimated that $10 \%$ of the project time was devoted to coordination meetings where theoretical background, field sampling projects, and results were shared. Sub-groups of scientists were identified according to sub-topics to get a clearer idea of the project organization, but most people were simultaneously involved in several sub-groups in order to avoid being isolated. Segmentation into various sub-parts within different disciplines was relatively easy, with each person easily being able to identify what concerned his or her area of competence. The project was a continuation of previous research activities that had already delineated sub-topics according to a systemic analysis of the research questions. The researchers developed a set of specific themes, anchored in their respective disciplines, but maintained close ties with the project's structuring orientation. However, this was sometimes more difficult, especially when partners belonged to other teams and institutes, and there were not daily opportunities for meetings and discussions. Whenever possible, trainees and $\mathrm{PhD}$ candidates were co-supervised by two scientists for two reasons: to reinforce the strength of the collaborations, and to train future new scientists in interdisciplinary projects. Data sharing in these cross-collaborations and through GIS activities provided a good way to generate new interactions because the data needed to be formalized according to GIS standards, which necessitated a detailed explanation of their content, their origin, and their destination.

\section{THE METHODOLOGICAL ASPECTS OF THE PROJECT}

\section{A Common Nested Set of Sampling Areas}

The choice of the study region was preordained because it had been one of the research unit's main study areas for 15 years, thus there was a large set of data available and much knowledge had been acquired regarding the ecological (for the most part) and social processes taking place there (Sauget and Balent 1993, Deconchat 1999). The study sites are located in a small area in the Gascony hillsides, southwest of Toulouse (France); they include a mix of cropland, pastures, and small coppice woodlots (Balent and Courtiade 1992). Agriculture is the main activity in the area, but it is encountering difficulties in marginal areas that do not have particularly high agricultural potential. The social system is traditionally organized in "houses" that correspond to well-identified land domains, names, and social roles, which, in particular, determine the inheritance process (the "house" is passed on to the eldest son in most cases) and cooperative relations between neighbors (Sourdril et al. 2006).

This region was considered an "intermediate zone" without any particular conservation value, agricultural potential, or social challenge. Conversely, it was also considered representative of what can be seen across large parts of southwestern France. Our closer analysis of the situation during the project identified several specific features of this area, such as the fact that there is a high proportion of new inhabitants from the north of Europe.

Several sub-parts of the study region were more intensively sampled, to cover fine- and large-scale processes, according to the sampling constraints imposed by each discipline. For example, ethnological studies were restricted to two small communities, whereas we analyzed fragmentation effects on biodiversity on a sample of 200 woodlots spread over a $30 \times 30 \mathrm{~km}$ square. However, the team chose the samples in such way that they were superimposed on each other as much as possible and nested (Fig. 1).

\section{Comparative and Spatialized Samples}

Each sub-group of scientists was responsible for data collection and analysis, according to their respective disciplines, and each was largely autonomous in their methodological and technical choices. The main assumption was that team members could adapt their detailed research choices in relation to the established general framework and the constraints imposed by the study area. The ecological studies were based on two main approaches: 1) point samples from contrasting sites along a gradient for comparative analysis, using statistical ordination methods; and 2) species distribution mapping in one (transect) or two dimensions. Experimental designs were rarely used, 
Fig. 1. Overlapping samples on the same study area. The study area was located in southwestern France, near Toulouse, in a rural region with croplands and pastures as a matrix (white) surrounding small woodlots and a few larger forests (green); towns, villages, and rivers are grey. The interdisciplinary research project had several sampling areas (shown by ellipses) according to the question addressed, but they overlapped as much as possible. The largest ellipse (dotted line) represents studies of bird/syrphid diversity in fragmented forests; the dashed-line ellipse represents tree diversity studies; the narrow red line ellipse represents roe deer and bird community dynamics; and the smallest ellipse (bold red line) represents fine-scale ecological studies combined with forestry and social studies that need detailed data (see Fig. 2).

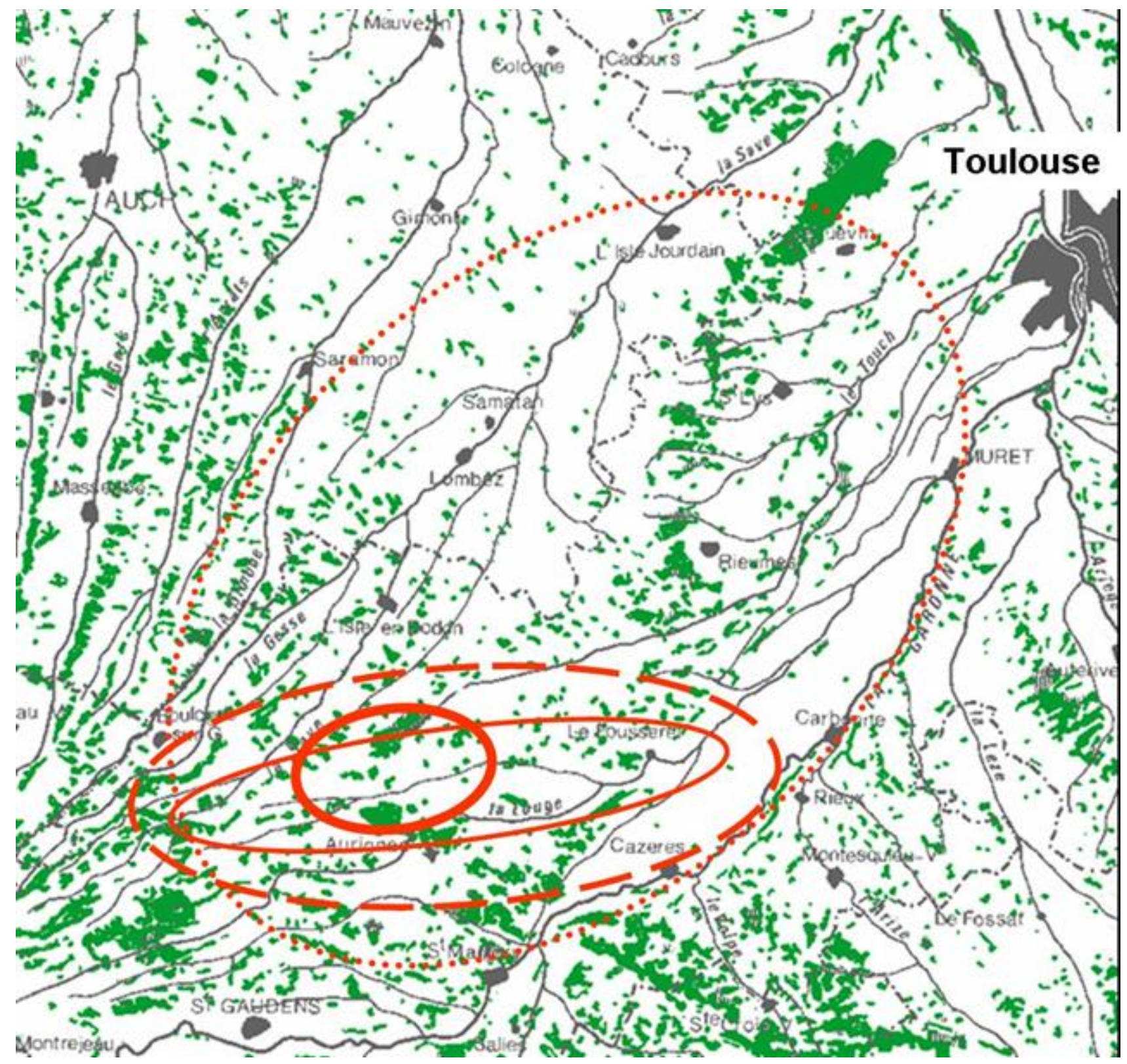


mainly because of the difficulty in controlling factors at the landscape level and on private land holdings. We studied plants (ligneous and herbaceous species separately), birds, syrphids (insect: diptera), and Roe deer-whenever possible, on the same plots in order to compare their responses to the same sets of factors. The sociologists adopted an ethnological approach based on a detailed analysis of a case study, restricted to the two central villages in the study area, conducting repeated open interviews with most of the stakeholders about their activities, their practices, their life, and their relationships with the other inhabitants. This study was completed by an historical compilation of the dynamics of the various households, with a retrospective mapping of past ownership and practices.

In order to facilitate the comparison of sets of data bearing on different aspects (Gibon 2003), data collection was planned and coordinated as much as possible by choosing common sites, synchronizing measurements, collectively establishing protocols, and sharing data management tools. However, the nature of the data, their collection methodology, and their end use were heterogeneous, particularly because they concerned different systems or were collected in contexts that have changed. This was particularly true for old data that we wanted to use to answer questions for which they were not designed. The metadata - data describing the data -implemented within the framework of a quality approach defining management procedures, provided a solution for making sustainable and reliable use of the collected data. The GIS, associated with relational databases, provided a practical but as yet incomplete solution for implementing these provisions. The GIS can be considered as a first-level model insofar as the subjacent relational tables define the links between the items of data, but it is generally insufficient because it does not provide any information on the generalization that can be made of its relations in other contexts (Rouet 1991).

\section{INTERDISCIPLINARY AND COLLECTIVE RESULTS}

Data sets produced by the project were the basic unit of the project productivity and offered the opportunity to interact between different disciplines. Each data set was analyzed according to the questions and methodology of the discipline it was related to. We do not present these results here. In a second step, and in relation to the project objectives, we considered the data sets from the point of view of their interactions and comparisons. We present four main general results obtained from this step that show how the interdisciplinarity of the project allowed us to identify patterns that would not have been identified by projects of narrower scope.

\section{Biodiversity Seen from Different Species Groups}

The botanists, entomologists, and ornithologists involved in the project agreed that the biodiversity of the studied woodlots was not of particularly high conservation value, even though some rare species (particularly insects) have been found locally. There were, however, trends related to the biodiversity that may be of concern in the future: e.g., a highly significant reduction of $15 \%$ in the total number of birds over a 20 -year period across a small region. Sites where joint observations were carried out make it possible to compare the responses of these groups, e.g., to show that, although large woods still had the richest species diversity, for all taxonomic groups considered, a set of small woods representing a comparable overall surface area contained a higher number of species (Table 1) (Monteil et al. 2005, Ouin et al. 2006). This joint response underlined the need to consider biodiversity management at different scales and, in particular, at a large scale encompassing several woodlots.

\section{Ecological and Social Interfaces}

Biodiversity on the edges of the woodlots was different from that observed in areas deeper within, to varying degrees for all the groups studied. There was often a greater number of species on the edges, but they were generally more ubiquitous than the limited species inside the woodlots. Roe deer and Episyrphus balteatus (beneficial syrphid species feeding on wheat aphids) had a particular affinity for the edges, which represent important elements for their population dynamics by providing them with shelter and food resources at key moments in their lives (Coulon et al. 2004, Sarthou et al. 2005). This ecological phenomenon, also called edge effect, is known (Cadenasso et al., 2003), but it was 
Table 1. The biodiversity of wooded fragments in the Gascony hillsides

\begin{tabular}{lccc}
\hline \hline & Ligneous plants & Birds & Syrphids (Dipterous) \\
\hline Total species richness in all wooded areas & 77 & 29 & 114 \\
Species richness in a large wood (150 ha) & 45 & 21 & 68 \\
Total species richness in ten woodlots, having a total surface & 60 & 22 & 74
\end{tabular}

coupled in our case study by a sociotechnical phenomenon revealed by the study of management practices in those same woods (Sourdril et al. 2006). A link between ecological structures in the landscape, including edges, and their social boundaries was identified (Fig. 2). Indeed, the edges were very often exploited differently than the rest of the forest, in particular, having a specific cutting frequency (du Bus de Warnaffe et al. 2006) (e.g., Fig. 3). Interviews with woodlot managers showed that their choices were the result of forestry-related decisions, but were also influenced by the use of the adjacent farm plots, for which the edges can either be a hindrance (in the case of crops), or an advantage (in the case of fields because they provide shelter for animals). Therefore, it seemed that there were ecological, agro-zootechnical, and social issues around the woodlot edges that deserve particular attention.

\section{Forest Practices that Generate Ecological Heterogeneity}

A retrospective analysis of practices in woodlots showed that there were two characteristics of forestry management which, at first sight, are contradictory (du Bus de Warnaffe et al. 2006). It is influenced by both tradition and opportunity. The owners attach a great deal of importance to preserving their forest heritage and to maintaining its productivity, but they have difficulty envisaging changing its characteristics, e.g., by means of plantation. They frequently referred to the traditional dimension, excluding the production demands of farming, in their interviews. At the same time, this long-term view is modified day-by-day according to the opportunities and constraints for determining the forestry and harvesting operations to be carried out, without any precise reference to an organized development plan. Therefore, cutting limits do not correspond to fixed plots, and harvest dates can be changed to suit the needs of the moment. The maps produced showed that the consequence of this management regime was a high level of heterogeneity in small woodlots, resulting from repeated disturbances affecting areas with changing shapes (du Bus de Warnaffe et al. 2006) (Fig. 4).

\section{Farming and Forestry Relationships}

Agricultural statistics may appear to show that the link between farming and woodlots is weakening because fewer and fewer farms officially incorporate woodlots (Normandin 1996). However, our more detailed approach, involving ethnographic interviews, showed that this covered a variety of situations and corresponded more to a change in the relationship than to a rupture. Indeed, from a functional viewpoint, woodlots very often remained an integral part of the farming operation thanks to arrangements between retired farmers, who were in charge of forestry, and their successors, the active farmers, who were in charge of the farms. The study revealed the nature of these relationships, highlighting that, although the retired farmers were the owners, their sons increasingly took part in the forestry work, where decisions were generally taken jointly. However, new practices seem to be appearing in forestry operations, and may change ecological conditions (Sourdril et al. 2004) (Fig. 3). 
Fig. 2. The dynamics of human and ecological limits. A fine-scale ethnological study, combining historical maps of land registration, "house" history acquired from interviews, and aerial photographs identifying social units (houses) and ecological features (hedges, woodlot edges, riparian corridors) that may be used to define limits (maps on the left). The historical analysis (right-hand map) shows that most of thewithin-house limits have disappeared, whereas inter-house limits have been maintained or created between 1942 and 2002. This example illustrates how social constraints shape the landscape and may influence ecological processes, because hedges, woodlots, and riparian corridors are known to be of prime importance for biodiversity dynamics in fragmented landscapes. Such a study needs detailed data that cannot easily be obtained for a large area; it has been repeated for 43 houses. Credit: INRA; IGN, BD ORTHO, 2007
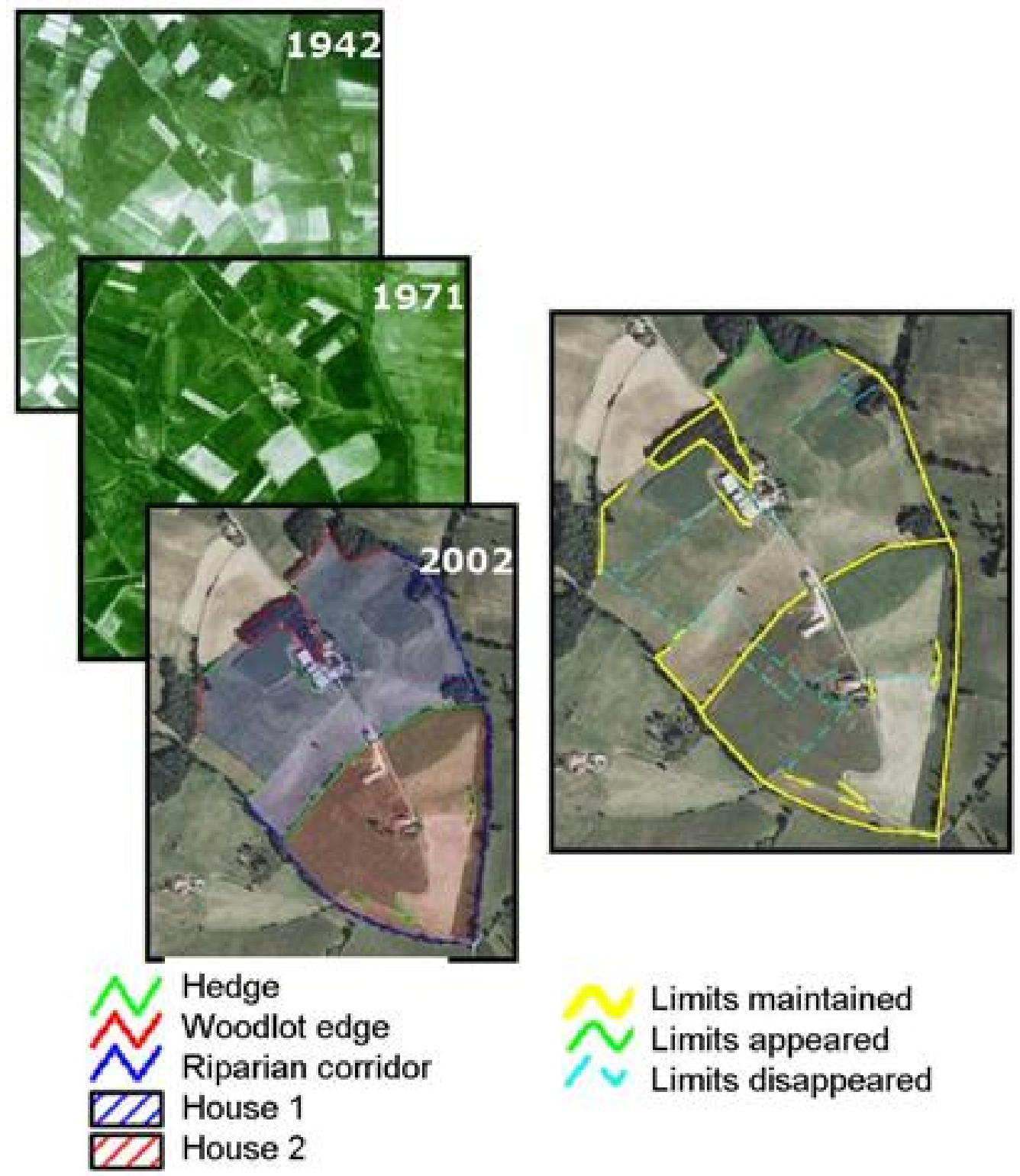

\section{Limits maintained}

Limits appeared Limits disappeared 
Fig. 3. Old and new practices. On the left, logging done by a retired farmer who had carefully cleared the ground of branches and piled the logs, even small ones, as was done in the past. On the right, logging done by a younger, active farmer, who had roughly piled the largest logs, in order to work more rapidly. This example illustrates that forestry practices are changing and may have new ecological consequences, with a greater quantity of organic matter probably being left on the ground in the latter case. The traditional chestnut coppice structure, with a few oak standard trees, can be seen in both pictures. On the right, the trees in the background are a narrow fringe purposefully left along the woodlot edge, illustrating that a specific management is often applied to edges. Credit: A. Sourdril.
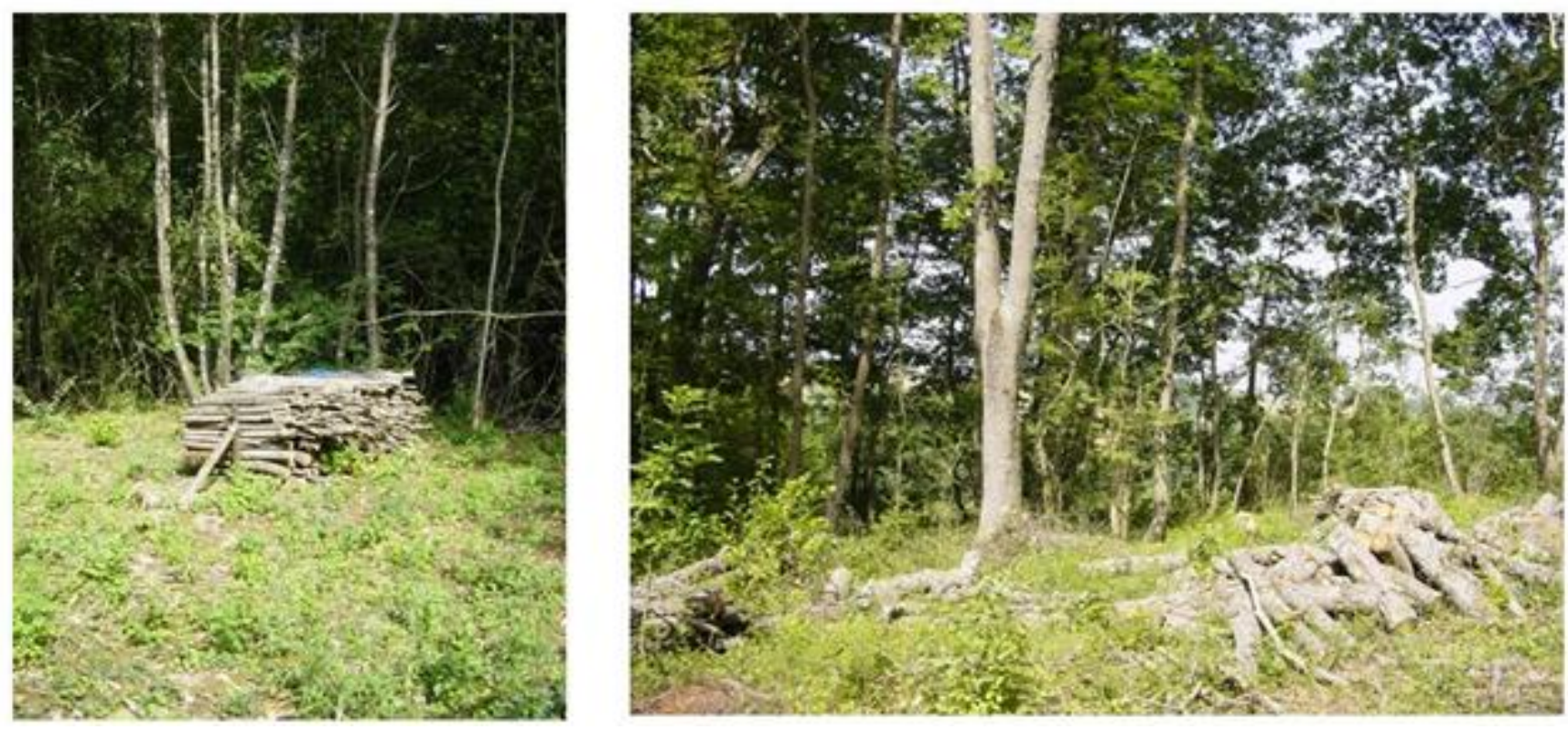

\section{Consequences for Regional Development}

As a result of this project, the landscape scale was recognized as being a critical level of concern for biodiversity questions in regional development that needs specific attention. The relationships between NIPFs and agriculture have been clearly identified as a dominant feature in regional rural landscapes. We try now to explain the importance of these relationships to the regional agencies for forestry and agricultural development, which are independent of each other, to help them to consider how to adapt their policies. For example, forest eco-certification, through the Pan-European Forest certification process, did not address the specifics of NIPFs, despite their regional importance for raw pulpwood production. We argue that better knowledge of the social and ecological characteristics of these forests would reinforce the credibility and success of this eco-certification process.

\section{DISCUSSION AND PROPOSAL BASED ON EXPERIENCE}

\section{Modular Research Framework}

Building on the experience gained, our first practical proposal for an interdisciplinary research framework, within which to take up the challenges of linking ecological and social questions, is to design modular research projects backed by flexible methodological choices (Gibon 2003). This organization has demonstrated its capacity for ensuring the coherence and flexibility of the research work. Splitting the project into sub-parts is not a reductive approach if different scales are studied simultaneously and if the methodologies are chosen to be compatible. The holistic view of the research question must frame the project, but it is not a day-to-day approach of current scientific work. 
Fig. 4. From ecological processes to the stakeholders' practices. A part of the interdisciplinary research project carried out on the same woodlots of southwestern France: 1) on the left, ecological studies of biodiversity, with plots identifying locations of individual birds of different species represented by different colors, 2) in the middle, forestry studies of woodlot structure, represented by polygons of different tree composition and structure, and by dots for valuable standard trees, and 3) on the right, ethnological studies of stakeholders' motivations and relationships, represented by the three main stakeholders (owner, user, neighbor) and their interactions (du Bus de Warnaffe et al. 2006).

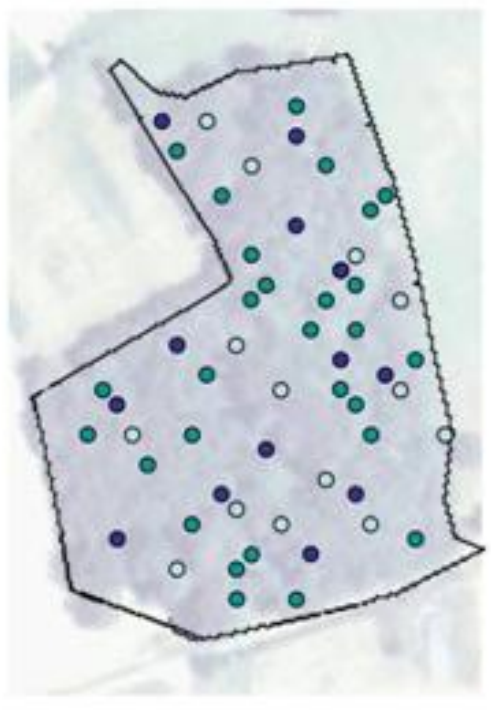

Biodiversity

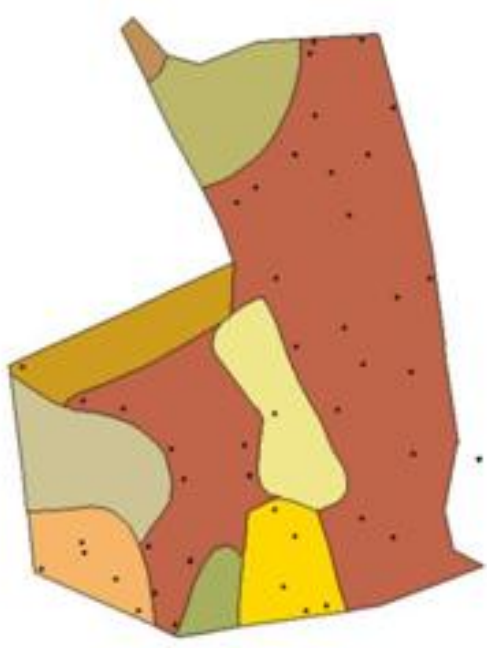

Forest structure

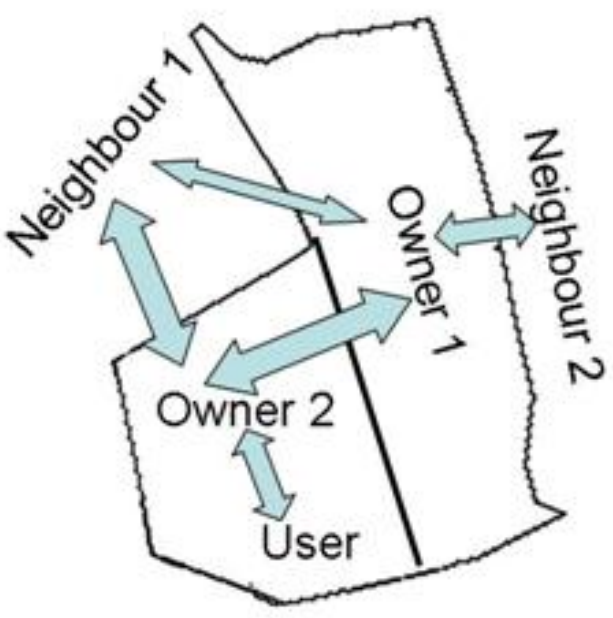

Stakeholders
The key factor in designing such modular frameworks, in our opinion, is the necessity for cross-communication between scientists, which could, perhaps, be very time consuming and not stimulating for some participants (Pickett et al. 1999). Accepting the need for this effort in communication, i.e., listening to people discussing things not directly related to your own work, and presenting your work to people who are not directly involved in it, is a major factor influencing the ability to co-build the project and the results. Furthermore, organizing the interdisciplinary aspects is time consuming, and sometimes includes questioning and debate phases. Participants must be made aware of these points, and accept their costs in terms of scientific productivity and effort to consent.
Field visits are an especially efficient way of sharing points of view concerning real objectives. A passive level of communication (listen-tell) is not sufficient. Trust between the partners is another level of communication that allows them to interact and formulate opinions about an idea, even when they are not specialists on the topic. This is the way to generate new interactions and hypotheses, and to shift from a multidisciplinary work strategy to an interdisciplinary one. This trust can only be obtained if all participants put their egos aside, if meetings are chaired patiently by a leader, and, above all, if participants spend enough time together. Informal and personal aspects must be taken into account as well, because they may have considerable weight in this process (Jakobsen et al. 2004). A discussion leader, with a certain amount of experience, can greatly facilitate these interactions. A core 
discipline, such as landscape ecology, which is genuinely linked to other disciplines, also plays positive role in facilitating communication (Haber 2004). We think that an interdisciplinary project with concentric components around a central axis, where the disciplines are not balanced, is a stabilizing factor that regulates the project development in its centrifugal dispersion tendency.

\section{Evolvable Framework}

Constructing an interdisciplinary framework is a long and sometimes arduous task requiring regular updating, and the answers obtained often require a certain length of time to identify the slow and not particularly perceptible changes (Roybin et al. 2001). The framework flexibility and responsiveness must be situated between the rigidity and cumbersomeness of an over-integrated framework with orientations, and an operational implementation defined with too many facts, and an unstructured framework, which would lose sight of its initial objectives as it evolves. The arrival and departure of participants during a long-term project requires a sustained and continuous effort to ensure a collective coherence (Roybin et al. 2001). The evolution of the research framework must be anticipated, even if the forms it will take are not known in advance. To allow for this evolution, continuity must first be ensured, that is to say, the means of collectively capitalizing on what has been gained (data, results, methods, hypotheses) must be put in place, and these means must be evaluated with regard to the initial objectives (Pickett et al. 1999). It is at the time of this evaluation that the group of researchers, possibly in conjunction with the social partners involved in what is at stake, will determine the collective evolutions that are to be reflected at the level of the framework sub-parts. A serious difficulty lies in how to integrate into the project the skills of new people, who do not share the initial participants' experience of longer cooperation. It is often necessary to examine the framework from every angle and review implicit points that are no longer discussed because they have already been confirmed. This in fact limits the possibility for extending the framework to avoid constantly being in the process of being redefined.

The perception of the progression of the project by the participants is acknowledged to play a major role in its success (Jakobsen et al. 2004). The different disciplines do not progress at the same speed, and this can give some people the feeling that they are being "held back" by other participants. The research time steps are not the same in all disciplines; some produce results more quickly than others. This asynchronism can pose problems because the knowledge in one domain could influence studies still in progress in another domain, whose methodology, however, cannot be modified quickly for fear of invalidating the work already carried out.

\section{From the Case Study to Generalization}

The convergence and interaction of the various parts of the research framework must bear on a set of scientific questions and objectives seen according to their multiple facets. To do this, as the questions are territorial, it is necessary to decide on a common workshop site. The social demands and the partners may be sufficient for determining it, but it may also result from a scientific choice without any prior identification of the local social challenges, provided that the site is considered to be representative of a broader set of situations. The workshop site may include several fields of research corresponding to different scales but, as much as possible, the questions concerning any given spatial scale would gain from being studied in the same place. The sometimes long and cumbersome setting-up of such frameworks means that a partnership must be established with the actors from the territory in order to obtain their agreement, to make it possible to access the information they have, and possibly, to ask them to carry out experiments. This can represent the first step toward a more participative type of research.

A case study could be a "scientific trap" if the knowledge gathered and produced by its analysis happened to be useful only for its questions. The ability to formalize, to generalize the results, and to apply them to other situations is of prime importance. This implies three constraints: 1) when necessary, use samples with a variability larger than the actual variability observed in common situations, or sample outside the study area of interest to get comparative references; 2) develop the sampling design in cooperation with the other members of the project in order to maintain intercompatibility; and 3) formulate the results in the frame of a model that can be transposed to other situations (Pickett et al. 1999, Heemskerk et al. 2003). Regarding the last point, we think that multi- 
agent system models currently provide very promising tools for aggregating disparate sets of knowledge on ecological and social systems (Bousquet and Lepage 2004).

The management of the data collected represents a key factor for an interdisciplinary research framework. A GIS is a useful tool for that purpose, but the concept should be enlarged to more general information systems that are able to collect, organize, analyze, and display all the different pieces of information gathered and produced during a project. This would be especially useful in the future for re-analyzing the data in light of new questions and new projects. The integration of an individual research project, on a given area, into international research networks for long-term studies on the relationships between activities, territories, and biodiversity will be facilitated by such information management. This is a way to benefit from the methodological advances made by other participants and to confront results with those obtained in other ecological and social situations (Redman et al. 2004).

Responses to this article can be read online at:

http://www.ecologyandsociety.org/vol12/iss 1/art15/responses/

\section{Acknowledgments:}

This work was partially supported by the French INRA program PSDR (Pour et Sur le Développement Régional) and was originally presented at the INRA symposium "Territoires et Enjeux du Développement Régional," Lyon, France, 9-11 March 2005. Our research work has benefited from the financial backing of INRA, Midi-Pyrénées Region, and the Quantitative Ecology ACI. Currently, it is supported by CNRS (Workshop Zones Program) and ECCO ACI (PNBC Program). We would like to thank Mr. de Galard (former President of the Haute-Garonne Chamber of Agriculture, Mayor of the municipality of St-André) for the highly positive reception he has always afforded our research and for the material facilities placed at our disposal in the field, and all the farmers and inhabitants of the municipality in the Nère valley for their understanding in the face of the diurnal and sometimes nocturnal activities of the researchers. We would also like to extend our thanks to Laurent Burnel, Laurent Raison, and Jérôme Willm, technicians at the UMR Dynafor, for their participation in the fieldwork, and the numerous trainees who have accompanied us in our research work. An earlier version of this paper was improved by comments from J. C. Menaut, D. Salles, G. Dedieu, P. Gouaux, B. Bouyjou, M. Gonzalez. H. ap Thomas, and A. Maricourt helped improve the English version of the text.

\section{LITERATURE CITED}

Abel, T., and J. R. Stepp. 2003. A new ecosystems ecology for anthropology. Conservation Ecology 7: 12. [online] URL: http://www.ecologyandsociety.org/ vol7/iss3/art12/.

Allen, T. F. H., and T. B. Starr. 1982. Hierarchy. Perspectives for ecological complexity. The University of Chicago Press, Chicago, Illinois, USA.

Balent, G. 1987. Structure, fonctionnement et évolution d'un système pastoral. Le pâturage vu comme un facteur écologique piloté dans les Pyrénées centrales. Dissertation, Université de Rennes, France.

Balent, G. 1996. La forêt paysanne dans l'espace rural. Biodiversité, paysages, produits. Études et Recherches sur les Systèmes Agraires et le Développement 29:1-268.

Balent, G., D. Alard, V. Blanfort, and I. Poudevigne. 1999. Pratiques de gestion, biodiversité floristique et durabilité des prairies. Fourrages 160:385-402.

Balent, G., and B. Courtiade. 1992. Modelling bird communities/landscape patterns relationships in a rural area of south-western France. Landscape Ecology 6:195-211.

Balent, G., and A. Gibon. 1999. Organisation collective et individuelle dans la gestion des ressources pastorales: conséquences sur la durabilité agro-écologique des ressources. Options Méditerranéennes Série B 27:267-277.

Berkes, F. 1999. Sacred ecology: traditional ecological knowledge and management systems. Taylor and Francis, Philadelphia, Pennsylvania, USA. 
Berkes, F., and C. Folke, editors. 1998. Linking social and ecological systems. Management practices and social frameworks for building resilience. Cambridge University Press, Cambridge, UK.

Bingeman, K., F. Berkes and J. S. Gardner. 2004. Institutional responses to development pressures: resilience of social-ecological systems in Himachal Pradesh, India. International Journal of Sustainable Development and World Ecology 11(1):99-115.

Blandin, P., and M. Lamotte. 1985. Écologie des systèmes et aménagement : fondements théoriques et principes méthodologiques. Pages 139-162 in M. Lamotte, editor. Fondements rationnels de l'aménagement d'un territoire. Masson, Paris, France.

Boiffin, J. 2004. Dossier interdisciplinarité territoire : agronomie, géographie, écologie, où en est-on? Le point de vue d'un chercheur agronome. Nature, Sciences et Société 12(3):307-309.

Bousquet, F., and C. Le Page. 2004. Multi-agent simulations and ecosystem management: a review. Ecological Modelling 176(3-4):313-332.

Cadenasso, M. L., S. T. A. Pickett, K. C. Weathers, S. S. Bell, T. L. Benning, M. M. Carreiro, and T. E. Dawson. 2003. An interdisciplinary and synthetic approach to ecological boundaries. BioScience 53:717-722.

Carlsson M., M. Andersson, B. Dahlin, and O. Sallnas. 1998. Spatial patterns of habitat protection in areas with non-industrial private forestryhypotheses and implications. Forest Ecology and Management 107(1-3):203-21.

Chapin, F. S. I., E. D. Schulze, and H. A. Mooney. 1992. Biodiversity and ecosystem processes. Trends in Ecology and Evolution 7:107-108.

Coulon, A., J. F. Cosson, J. M. Angibault, B. Cargnelutti, M. Galan, N. Morellet, E. Petit, S. Aulagnier, and A. J. M. Hewison. 2004. Landscape connectivity influences gene flow in a roe deer population inhabiting a fragmented landscape: an individual-based approach. Molecular Ecology 13:2841-2850.

Deconchat, M. 1999. Exploitation forestière et biodiversité : exemple dans les forêts fragmentées des coteaux de Gascogne. Thesis, Université de Toulouse III, France.

Deffontaines, J. P., C. Thenail, and J. Baudry. 1995. Agricultural systems and landscape patterns. How can we build a relationship? Landscape and urban planning 31:3-10.

Delattre, P. 1985. Recherches interdisciplinaires. Pages 1261-1266 in Encyclopaedia Universalis France, S.A., editor. Encyclopaedia Universalis, Corpus 9. Paris, France.

Di Pietro, F., and G. Balent. 1997. Dynamique des pratiques pastorales et des paysages: une approche pluri-échelles appliquée aux Pyrénées ariégeoises (France). Agronomie 17:139-155.

du Bus de Warnaffe, G., M. Deconchat, S. Ladet, and G. Balent. 2006. Variability of cutting regimes in small private coppice forests of south-western France. Annals of Forest Sciences 63:915-927.

Ellen, R. F. 1982, Environment, subsistence and system: the ecology of small-scale societies. Cambridge University Press, Cambridge, UK.

Folke, C., C. S. Holling, and C. Perrings. 1996. Biological diversity, ecosystems, and the human scale. Ecological Applications 6:1018-1024.

Forman, R. T. T., and M. Godron. 1986. Landscape Ecology. John Wiley, New York, USA.

Gibon, A. 2003. Les systèmes d'élevage en ferme. Un champ en émergence de la zootechnie entre filière et territoire. Habilitation à Diriger des Recherches, INP Toulouse, France.

Haber, W. 2004. Landscape ecology as a bridge from ecosystems to human ecology. Ecological Research 19:99-106.

Heemskerk, M., K. Wilson, and M. PavaoZuckerman. 2003. Conceptual models as tools for communication across disciplines. Conservation Ecology 7(3): 8. [online] URL: http://www.ecology andsociety.org/vol7/iss3/art8/.

Holling, C. S. 1998. Two cultures of ecology. Conservation Ecology 2(2): 4. [online] URL: http:/ /www.ecologyandsociety.org/vol2/iss2/art4/.

Holling, C. S. 2001. Understanding the complexity 
of economic, ecological, and social systems. Ecosystems 4:390-405.

Huston, M. A. 1994. Biological diversity. The coexistence of species on changing landscapes. Cambridge University Press, Cambridge, UK.

Inventaire Forestier National (IFN). 2006. La forêt française. Résultats de la campagne de levés 2005. Inventaire Forestier National. Nogent sur Vernisson, France.

Jakobsen, C. H., T. Hels, and W. J. McLaughlin. 2004. Barriers and facilitators to integration among scientists in transdisciplinary landscape analyses: a cross-country comparison. Forest Policy and Economics 6:15-31.

Jollivet, M. 1992. Pluridisciplinarité, interdisciplinarité et recherche finalisée ou des rapports entre sciences, techniques et sociétés. Pages 519-535 in M. Jollivet, editor. Sciences de la Nature, Sciences de la Société. CNRS Editions, Paris, France.

Jollivet, M., and A. Pavé. 1993. L'environnement : un champ de recherche en formation. Natures, Sciences et Sociétés 1:6-24.

Legay, J. M. 2006. L'interdisciplinarité dans les sciences de la vie. Cemagref éditions, CIRAD, Ifremer, INRA éditions, Paris, France.

Maczko, K. A., L. D. Bryant, and D. W. Thompson. 2004. Putting the pieces together: assessing social, ecological, and economic rangeland sustainability. Rangelands 26(3):3-14.

Monteil, C., M. Deconchat, and G. Balent. 2005. Simple neural network reveals unexpected patterns of bird species richness in forest fragments. Landscape Ecology 20(5):513-527.

Normandin, D. 1996. La forêt paysanne en France : état des lieux et perspectives d'évolution. Etudes et Recherches sur les Systèmes Agraires et le Développement 29:195-211.

Olsson, P., C. Folke, and F. Berkes. 2004. Adaptive comanagement for building resilience in socialecological systems. Environmental Management 34 (1):75-90.

Ouin, A., J. P. Sarthou, B. Bouyjou, M. Deconchat, J. P. Lacombe, and C. Monteil. 2006.
The species-area relationship in the hoverfly (Diptera, Syrphidae) communities of fragmented forests in southern France. Ecography 29(2):183190. DOI : $10.1111 / \mathrm{j} .2006 .0906-7590.04135 . \mathrm{x}$.

Papy, F. 2001. Pour une théorie du ménage des champs : l'agronomie du territoire. Comptes Rendus des Séances de l'Académie d'Agriculture de France 87:139-149.

Pickett, S. T. A., W. R. Burch, and J. M. Grove. 1999. Interdisciplinary research: maintaining the constructive impulse in a culture of criticism. Ecosystems 2(4):302-307.

Redman, C. L., J. M. Grove, and L. H. Kuby. 2004. Integrating social science into the long-term ecological research (LTER) network: social dimensions of ecological change and ecological dimensions of social change. Ecosystems 7(2):161171.

Reid, J., L. Baker, and S. R. Morton. 1992. Traditional knowledge + ecological survey $=$ better land management. Search (Sydney) 23(8):249-251.

Rouet, P. 1991 Les données dans les systèmes d'information géographique. Éditions Hermès, Paris, France.

Roybin, D., P. Fleury, C. Béranger, and D. Curtenaz. 2001. Conduite de recherches interdisciplinaires en partenariat et apprentissages collectifs. Le cas du GIS Alpes du Nord. Nature Sciences Societes 9(3):16-28.

Sarthou J. P., A. Ouin, F. Arrignon, G. Barreau, and B. Bouyjou. 2005. Landscape parameters explain the distribution and abundance of Episyrphus balteatus (Diptera: Syrphidae). European Journal of Entomology 102(3):539-545.

Sauget, N. 1994. Of land, woods and men: farmers talk about the land, the evolution of woodland areas and the landscape. Landscape Issues 11(1):52-58.

Sauget, N., and G. Balent. 1993. The diversity of agricultural practices and landscape dynamics: the case of a hill region in the south-west of France. Pages 113-129 in R. G. H. Bunce, L. Ryszkowski, and M. G. Paoletti, editors. Landscape ecology and agroecosystems. Lewis Publishers, Boca Raton, Florida, USA. 
Sébillote, M. 1992. Pratiques agricoles et diversité végétale. Economie Rurale 208-209:95-99.

Sébillote, M. 2001. Des recherches en partenariat "pour" et "sur" le développement régional. Ambitions et questions. Natures, Sciences et Sociétés 9(3):5-7.

Sourdril, A., G. du Bus de Warnaffe, M. Deconchat, E. Garine, and G. Balent. 2004. Farm foresters in south western France: from father to son, differences in representations, ownership strategies and ecological consequences. Pages 107-112 in IUFRO Symposium on Human dimensions of family and farm forestry. Washington State University, Pullman, Washington, USA.

Sourdril, A., G. du Bus de Warnaffe, M. Deconchat, E. Garine, and G. Balent. 2006. From farm forestry to farm and forestry in south-western France as result of changes in a "house-centred" social structure. Small Scale Forestry Management, Economics and Policy 5(1):127-144.

Southwood, T. R. E. 1995. Ecological processes and sustainability. International Journal of Sustainable Development and World Ecology 2:229-239.

Thornton, P. K., and P. G. Jones. 1998. A conceptual approach to dynamic agricultural landuse modelling. Agricultural Systems 57: 505-521.

Toledo, V.M. 1992. What is ethnoecology?: origins, scope and implications of a rising discipline. Ethnoecologica 1:5-21.

Walker, B. H., C. S. Holling, S. R. Carpenter, and A. Kinzig. 2004. Resilience, adaptability and transformation in social-ecological systems. Ecology and Society 9(2): 5. [online] URL: http://w ww.ecologyandsociety.org/vol9/iss2/art5/. 